WMJ (Warmadewa Medical Journal), Vol. 6 No. 1 Mei 2021, Hal. 20-29

\title{
Inpatient Facility Distribution and Primary Healthcare Centers Demand Based on Location-Quotient in Bali within 2015-2019 Period
}

\author{
Ni Made Hegard Sukmawati ${ }^{1 *}$, Anny Eka Pratiwi ${ }^{1}$, Luh Gede Pradnyawati ${ }^{1}$, DAP \\ Ratna Juwita ${ }^{1}$ \\ ${ }^{I}$ Department of Community Medicine/Preventive Medicine, Faculty of Medicine and Health Sciences, Univer- \\ sitas Warmadewa, F1 Building 3rd Floor, FKIK Universitas Warmadewa, Denpasar, Bali \\ E-mail': sukmawati.hegard@gmail.com
}

\begin{abstract}
The study of access to primary healthcare centers (PHCs) in the middle region of Indonesia, including Bali, is scarce. A study on primary healthcare access is worth undertaken in this region because it is usually given less attention regarding its fair distribution of healthcare facilities in relation to their population. This study aimed at determining geographical distribution and concentration of PHCs facility and demand in Bali Province. This study focused on the inpatient facility and demand of PHCs in relation to population. Data of PHCs' inpatient facility and demand of each regency/city and population data were obtained from Bali Health Profile of 2015 to 2019. Location quotients (LQ) of inpatient facility and inpatient demand for each regency/ city were calculated to determine the spatial concentration of the two variables compared to the provincial average. Our study found that there was variation in facility and demand for inpatient care in PHCs in Bali. A low level of inpatient facility and demand was seen in Regency of Buleleng, Denpasar, and Gianyar, while a high level of facility and demand for inpatient facility was observed in Regency of Jembrana, Tabanan, Klungkung, and Karangasem. A unique finding was also noticed in Bangli Regency, where the inpatient facility of PHC was high, while the inpatient demand was low. This might indicate a need for evaluation of the inpatient facility of PHC in this Regency.
\end{abstract}

Keywords: Access to healthcare, Bali, inpatient care, puskesmas, primary healthcare centers.

\section{Abstrak \\ [Distribusi Fasilitas dan Kebutuhan Pelayanan Rawat Inap Puskesmas Berdasarkan Location Quotient di Bali, Periode 2015-2019]}

Penelitian mengenai akses terhadap layanan kesehatan primer (Puskesmas) di wilayah Indonesia bagian tengah, termasuk Bali, masih sangat minim. Studi terhadap akses layanan kesehatan di wilayah ini perlu dilakukan mengingat seringkali mendapat perhatian yang lebih rendah dalam hal distribusi fasilitas pelayanan kesehatan terkait dengan populasinya di wilayah ini. Studi ini bertujuan untuk menggambarkan distribusi geografis fasilitas dan kebutuhan puskesmas di Provinsi Bali. Studi ini berfokus pada fasilitas rawat inap dan kebutuhan layanan rawat inap di puskesmas dikaitkan dengan populasi. Data fasilitas rawat inap dan kebutuhan layanan rawat inap puskesmas di setiap kabupaten/kota, serta data populasi diperoleh dari data Profil Kesehatan Provinsi Bali tahun 2015-2019. Location quotient (LQ) dari fasilitas rawat inap dan kebutuhan rawat inap puskesmas di masing-masing kabupaten/kota dihitung untuk menentukan konsentrasi spasial kedua variabel dibandingkan terhadap rerata pada tingkat provinsi. Tingkat fasilitas dan kebutuhan terhadap pelayanan rawat inap puskesmas yang rendah ditemukan di Kabupaten Buleleng, Denpasar, dan Gianyar, sedangkan tingkat fasilitas dan kebutuhan terhadap pelayanan rawat inap puskesmas yang tinggi ditemukan di wilayah Kabupaten Jembrana, Tabanan, Klungkung, dan Karangasem. Hasil yang unik ditemukan pada Kabupaten Bangli, dimana fasilitas rawat inap puskesmas menunjukkan tingkat yang tinggi, namun kebutuhan atas layanan rawat inap puskesmas di wilayah ini adalah rendah. Terdapat variasi dalam 
tingkat fasilitas dan kebutuhan layanan rawat inap puskesmas di Provinsi Bali. Evaluasi terhadap fasilitas layanan kesehatan rawat inap puskesmas perlu dilakukan di kabupaten dengan ketidakseimbangan antara suplai dan kebutuhan.

Kata Kunci: Akses layanan kesehatan, Bali, rawat inap, puskesmas

\section{Introduction}

Access to healthcare is an important issue in Indonesia and other developing countries. Achieving health-for-all remains an utmost priority of national development plans. Availability is one of the geographic dimensions of health access defined as the adequacy of the health facility and providers ${ }^{(1)}$. Based on this dimension, health care access is related to the opportunity to get health care when needed, and it is commonly measured using indicators such as the number of beds or doctors per capita. World Health Organization ${ }^{(2)}$ reports that there are inequalities in health care access, health service coverage, and outcomes in Indonesia. The government is currently progressing to improve health facilities and personnel as their supply and quality are disproportionate across the country. Several programs have been implemented by the government, such as building national capacity for health inequality monitoring, imposing universal healthcare program, improving geographic access to primary care with the Nusantara Sehat Program, as well as increasing the number of primary healthcare centers (Puskesmas).

The health care system in Indonesia has integrated preventive and curative medicine by the creation of Puskesmas. Puskemas is the primary healthcare centers (PHCs) in Indonesia and it is the first level of health facility in district jurisdiction. It deals primarily with primary health care (i.e., promotion, prevention, community empowerment), even though, to some extent, it also deals with curative care ${ }^{(3)}$.
PHCs also play a role as gatekeeper for referral to higher-level facilities such as specialized clinics and hospitals. Although the main roles of puskesmas have not changed significantly over time, particular Puskesmas also provide basic inpatient care. This inpatient facility was the result of the increased demand for inpatient care as the population expands over time.

Measuring inequalities of primary healthcare facilities and demand provide important information on identifying priority areas for program and policy response in an effort to narrowing the gap between the areas ${ }^{(2)}$. This information is critical during the planning of health sector program as all health measures should be equity-oriented. The analysis of healthcare supply and demand can serve as a platform to quantify and compare the resources and demand between areas and help determine priority area for appropriate responses. Thus, it is vital for policymakers to develop accurate measures of healthcare availability and accessibility (1). Several approaches and methods are available for measuring access to health, such as coverage approach, minimum distance, travel cost, etc. $\left({ }^{1,4-9)}\right.$. However, Photis ${ }^{(5)}$ proposed a methodological approach to determine the healthcare demand, supply, and service using location quotients. This method can quantify how concentrated a particular characteristic, phenomenon, or group is in an area compared to the larger region such as a nation ${ }^{(10)}$. In this respect, an LQ index is calculated by dividing the areal concentration by the national concentration, which quantifies the extent to 
which specific areas depart from the nation's average norm. This method is mostly used by researchers in economic geography to measure how concentrated a particular industry, occupation, or demographic group. One of the LQ method's significant attributes is its simplicity. The application of this method was implemented by Abdullahi and Abdullahi ${ }^{(1)}$ to determine the spatial concentration of health care facilities in Gombe State, Nigeria. This study found that unequal provision of health care facilities exists in the region.

The studies on access to Puskesmas in Indonesia were limited. Previous studies mostly focused on describing healthcare access in terms of financial barriers and analyzing the association of service quality and patients' satisfaction with certain health care services $^{(12-15)}$. Several studies on Puskesmas solely focused on human resources compared to physical access to health care $(16,17)$. A study by Nurcahyo and Bachtiar (16) measured the distribution of general practitioners in Puskesmas and found that $24.36 \%$ of Puskesmas lacked general practitioners, mostly located in Eastern Indonesia. The other study by Mujiati and Yuniar (17) measured the availability of human resources in primary health care centers in eight major cities in Java, while a study by Soewondo, Johar ${ }^{(18)}$ inspecting the facility, activity, and finance of primary health care centers in remote areas of Indonesia. Both studies revealed that there were insufficiencies in particular indicators of health care resources. On the other hand, the study of access to primary healthcare centers in the middle region of Indonesia, including in Bali, is scarce. A study on primary healthcare access is worth undertaking in this region because it is usually given less attention regarding its fair distribution of healthcare facilities in relation to their population.

Therefore, this study aimed to determine the geographical distribution and concentration of primary healthcare centers facility and demand in Bali Province. This study focused on PHCs' inpatient facility and demand in relation to population. Understanding this distribution will enable us to assess the areas with surplus and deficit healthcare facilities and be utilized to provide healthcare resource allocation.

\section{Methods}

\section{Data Collection}

Bali Province consists of eight regencies and a provincial city: Buleleng, Jembrana, Tabanan, Badung, Gianyar, Klungkung, Bangli, Karangasem, and Denpasar City. Data of PHCs' inpatient facility and demand of each regency/city, as well as data of population, were obtained from 2015 - 2019 Bali Health Profile ${ }^{(19-23)}$. These public documents were published by Bali Provincial Government Health Department and are available online on https:// www.diskes.baliprov.go.id/profil-kesehatan -provinsi-bali/. Inpatient facility was defined as the total number of beds in PHCs, and the inpatient demand was defined as the total number of patients admitted in PHCs. The data of facility and demand were also collected for each regency/city. Data of regency/city administrative boundaries were downloaded from www.indonesia-geospasial.com (24) and extracted by Geoda Software.

\section{Data Analysis}

PHCs' inpatient facility and inpatient demand data during 2015 to 2019 in Bali Province are presented as descriptive data in Table 2. Data was equipped with 


\section{WMJ (Warmadewa Medical Journal), Vol. 6 No. 1, Mei 2021, Hal. 23}

the percentage change in population, number of inpatient PHCs, number of PHC beds, and inpatient patients in PHC for the year 2015 to 2019 . The cumulative difference percentage of those variables was also determined to assess the overall trend of inpatient facility and inpatient demand throughout the study period. Location quotients (LQ) of inpatient facility and inpatient demand for each regency/city were calculated to determine the spatial concentration of the two variables compared to the provincial average.

A location quotient of inpatient facility was calculated based on the formula:

$$
F L Q_{i}{ }^{t}=\frac{B_{i}{ }^{t} / P_{i}{ }^{t}}{\sum_{i=1}^{9} B_{i}{ }^{t} / \sum_{i=1}^{9} P_{i}{ }^{t}}
$$

$B_{i}{ }^{t}$ is the number of PHC Beds in regen-

cy/city $\mathrm{i}$ and year $\mathrm{t}$, and ${P_{i}^{t}}^{t}$ is the total population at every regency/city i for year t.

Location quotient of inpatient demand was calculated based on the formula:

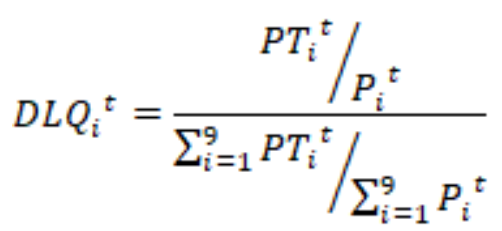

$P T_{i}^{t}$ is the number of patients admitted to

PHC in regency/city $\mathrm{i}$ and year $\mathrm{t}$, and $P_{i}{ }^{t}$ is the total population at every regency/city $i$ for year $t$.
LQ $>1$ indicates the high spatial concentration of inpatient primary healthcare facility/ demand in a regency/city compared to the average share of each regency/city. $L Q=1$ indicates a fair share of inpatient primary healthcare facility/demand involved in relation to a population. While $\mathrm{LQ}<1$ indicates a less than a fair share of inpatient primary healthcare facility/demand in a regency/city (11).

LQ data was joined with administrative boundary data using joins and related tools of ArcMap 10.3 and processed to produce a choropleth map. The LQ in the map was classified into five classifications (5), as shown in table 1.

Table 1. Location Quotient (LQ) categories

\begin{tabular}{ll}
\hline LQ Value range & Categories \\
\hline$<0.80$ & Very moderate \\
$0.80-0.94$ & Moderate \\
$0.95-1.08$ & Average \\
$1.09-1.20$ & Intense \\
$>1.20$ & Very intense \\
\hline
\end{tabular}

\section{Result}

This study found that the population of Bali Province was consistently increasing around $1.0 \%-1.1 \%$ each year from 2015 to 2019. Along with this increased population, the number of PHCs with inpatient care facility was also increasing, as well as the number of beds, except for 2016. However, the number of patients admitted to inpatient care in primary health care centers tended to decrease during the study period, with a cumulative difference percentage of $-63.1 \%$. The summary of this data is presented in Table 2 . 


\section{WMJ (Warmadewa Medical Journal), Vol. 6 No. 1, Mei 2021, Hal. 24}

Table 2. Primary Healthcare Centers' Inpatient Facility and Demand Data During 2015 to 2019

\begin{tabular}{ccccccccc}
\hline Year & Population & $\begin{array}{c}\Delta \text { Population } \\
(\%)\end{array}$ & PHC & $\begin{array}{c}\Delta \text { PHC } \\
(\%)\end{array}$ & PHC-beds & $\begin{array}{c}\Delta \text { PHC-bed } \\
(\%)\end{array}$ & Patients & $\begin{array}{c}\Delta \text { Patients } \\
(\%)\end{array}$ \\
\hline 2015 & $4,152,800$ & $0.0 \%$ & 38 & $0.0 \%$ & 436 & $0.0 \%$ & 18,289 & $0.0 \%$ \\
2016 & $4,200,100$ & $1.1 \%$ & 37 & $-2.6 \%$ & 426 & $-2.3 \%$ & 14,035 & $-23.3 \%$ \\
2017 & $4,246,500$ & $1.1 \%$ & 38 & $2.7 \%$ & 460 & $8.0 \%$ & 9,363 & $-33.3 \%$ \\
2018 & $4,292,200$ & $1.1 \%$ & 38 & $0.0 \%$ & 460 & $0.0 \%$ & 8,464 & $-9.6 \%$ \\
2019 & $4,336,900$ & $1.0 \%$ & 41 & $7.9 \%$ & 481 & $4.6 \%$ & 8,727 & $3.1 \%$ \\
Total & & $4.3 \%$ & & $8 \%$ & & $10.3 \%$ & & $-63.1 \%$
\end{tabular}

Note: Patient is defined as the number of patients admitted to the PHC to get inpatient care

Location quotient of an inpatient facility

The summary of the location quotient for PHCs inpatient facility in each Regency in Bali is presented in Table 3 and visualized by Figure 1. Based on this summary, we can see several Regencies whose LG indices were very moderate. These Re- gencies were Buleleng, Denpasar, and Gianyar. Badung Regency also had very moderate LQ indices in 2015 and 2016. However, the indices increased to average/ moderate from 2017 to 2019. The Regencies with high LQ indices were Jembrana, Tabanan, Klungkung, Bangli, and Karangasem.

Table 3. Location Quotient of Primary Healthcare Centers' Inpatient Facility, 2015 to 2019

\begin{tabular}{llllll}
\hline Regency/City & 2015 & 2016 & 2017 & 2018 & 2019 \\
\hline Buleleng & $\mathbf{0 . 5 9}$ & $\mathbf{0 . 6 1}$ & $\mathbf{0 . 7 1}$ & $\mathbf{0 . 7 1}$ & $\mathbf{0 . 6 8}$ \\
Jembrana & 1.75 & 1.80 & 2.01 & 2.02 & 1.95 \\
Tabanan & 1.90 & 1.96 & 1.82 & 1.83 & 2.10 \\
Badung & $\mathbf{0 . 5 4}$ & $\mathbf{0 . 5 5}$ & 0.92 & 0.91 & 0.86 \\
Denpasar & $\mathbf{0 . 2 6}$ & $\mathbf{0 . 1 5}$ & $\mathbf{0 . 1 4}$ & $\mathbf{0 . 1 4}$ & $\mathbf{0 . 1 3}$ \\
Gianyar & 1.25 & 1.28 & $\mathbf{0 . 6 4}$ & $\mathbf{0 . 6 4}$ & $\mathbf{0 . 7 9}$ \\
Klungkung & 1.14 & 1.17 & 1.93 & 1.94 & 1.56 \\
Bangli & 1.84 & 1.89 & 1.85 & 1.86 & 1.79 \\
Karangasem & 1.65 & 1.70 & 1.52 & 1.53 & 1.47 \\
\hline
\end{tabular}



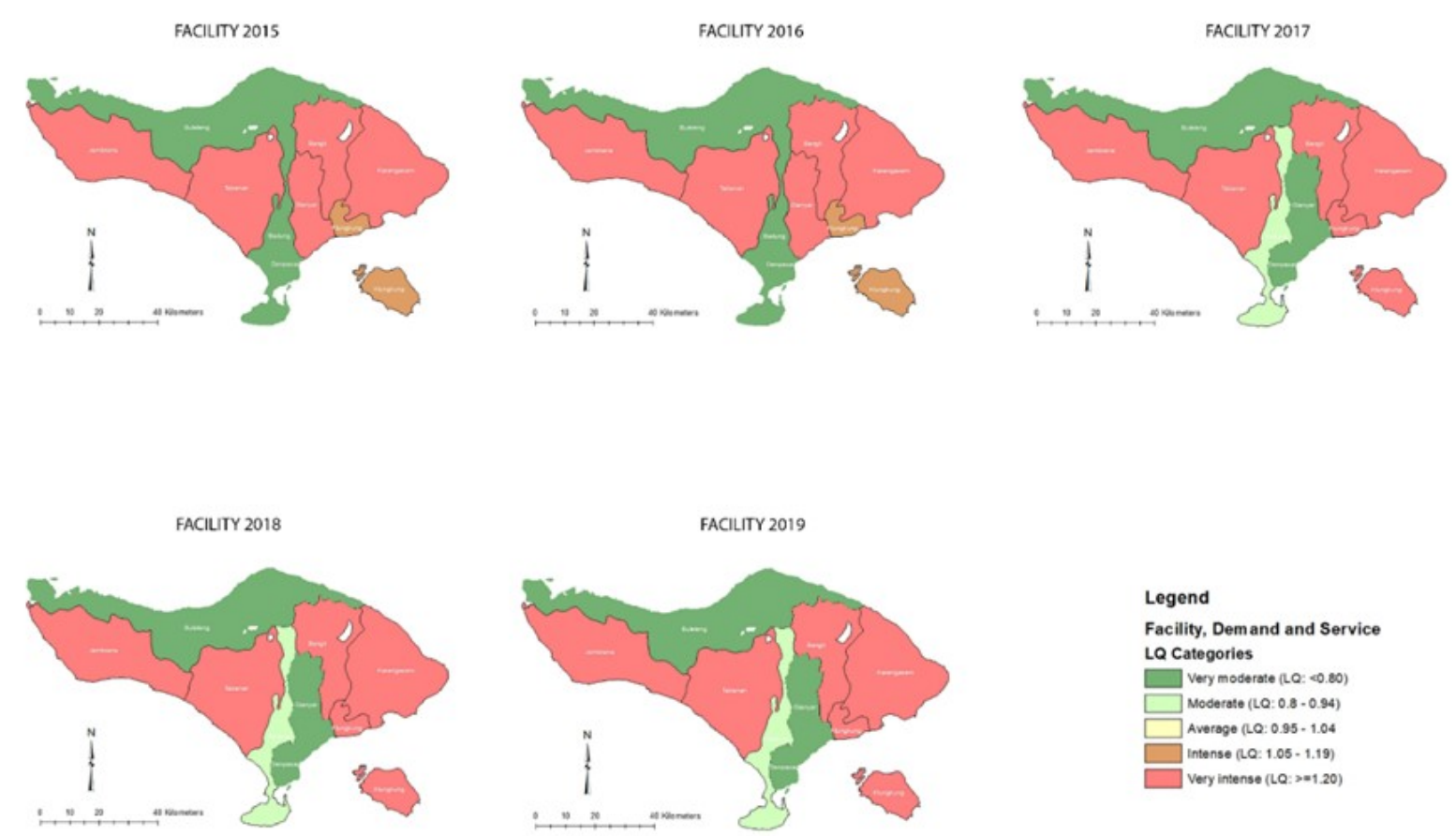

Figure 1. Location Quotient of Primary Healthcare Centers' Inpatient Facility, 2015 to 2019

Location quotient of inpatient demand

The inpatient demand in PHCs is illustrated in Figure 2 and Table 4. Based on this summary, high demand was observed in four Regencies, namely Jembra- na, Tabanan, Klungkung, and Karangasem. Although Bangli Regency had a high LQ index for an inpatient facility, this Regency showed relatively low demand for inpatient care, with the LQ index ranged from 0.08 to 1.00 .

Table 4. Location Quotient of Primary Healthcare Centers' Inpatient Demand, 2015 to 2019

\begin{tabular}{llllll}
\hline Regency/City & 2015 & 2016 & 2017 & 2018 & 2019 \\
\hline Buleleng & 0.28 & 0.40 & 0.06 & 0.31 & 0.33 \\
Jembrana & $\mathbf{5 . 3 3}$ & $\mathbf{3 . 7 3}$ & $\mathbf{4 . 9 1}$ & $\mathbf{4 . 0 6}$ & $\mathbf{5 . 6 6}$ \\
Tabanan & 0.69 & $\mathbf{1 . 3 0}$ & $\mathbf{1 . 8 6}$ & $\mathbf{1 . 4 4}$ & $\mathbf{1 . 3 3}$ \\
Badung & 0.14 & 0.39 & 0.36 & 0.43 & 0.35 \\
Denpasar & 1.57 & 0.09 & 0.34 & 0.84 & 0.45 \\
Gianyar & 0.73 & $\mathbf{1 . 2 0}$ & 0.84 & 0.41 & 0.43 \\
Klungkung & $\mathbf{1 . 2 4}$ & $\mathbf{1 . 7 4}$ & $\mathbf{2 . 2 1}$ & $\mathbf{1 . 7 4}$ & 0.99 \\
Bangli & 0.08 & 1.00 & 0.60 & 0.84 & 0.67 \\
Karangasem & 0.40 & $\mathbf{2 . 1 9}$ & $\mathbf{1 . 3 2}$ & $\mathbf{1 . 3 4}$ & $\mathbf{1 . 7 8}$ \\
\hline
\end{tabular}



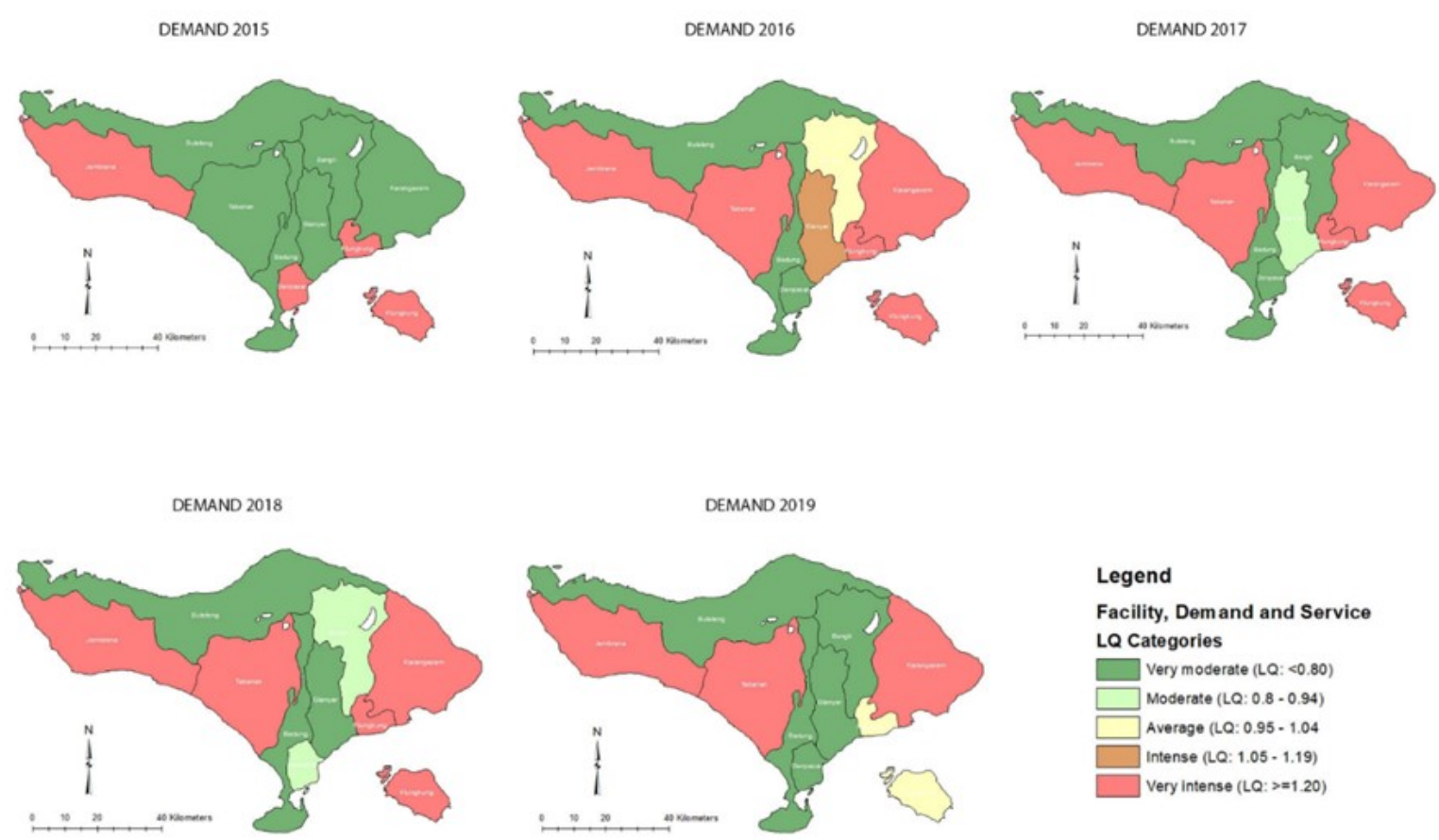

Figure 2. Location Quotient of Primary Healthcare Centers' Inpatient Demand, 2015 to 2019

\section{Discussion}

Using 2015 - 2019 Bali Health Profile data, this study was the first to determine the PHCs inpatient supply and demand in Bali to the best of our knowledge. According to our finding, it is apparent that while population, the number of PHC and beds were consistently increasing in Bali Province during the study period, the same did not account for the number of patients. The cumulative percent increase of beds was $10.3 \%$, while the number of patients showed a declining tendency to $-63.1 \%$. This discrepancy might be related to public perception towards inpatient care service in primary healthcare centers. According to a study by Rizki ${ }^{(25)}$ that patients' sense, feeling, and thinking have affected the decision whether they will reuse and advocate the inpatient care service in PHCs. They also argued that the patients had poorly rated the non-medical facilities. These facilities included the parking space, the sanitation of restrooms, foods, and other non-medical facilities. In contrast, a study by Soewondo, Johar (18) on patients' satisfaction on the PHCs inpatient care found that the patients' satisfaction varied depending on the location of PHC. Patients in urban areas have lower satisfaction with the PHC's inpatient care service compared to patients in rural and remote areas.

In this study, we employed a location quotient (LQ) index to quantify and compare inpatient care supply and demand in PHC across regencies. LQ is a method used to determine how concentrated or dispersed a particular facility or characteristic is in an area compared to a larger area. In this case, it is Regency versus Province. Based on this method, we found a high variation in allocation and distribution of PHCs inpatient facility in Bali Province. This indicates that some regencies of Bali have more inpatient facilities than others. Beyond expected, major urban areas of $\mathrm{Ba}$ - 


\section{WMJ (Warmadewa Medical Journal), Vol. 6 No. 1, Mei 2021, Hal. 27}

li, such as Buleleng, Denpasar, and Gianyar, had low LQ indices, which ranged from 0.13 to 0.79 . If we infer this roughly, this means that the three Regencies had an insufficient number of inpatient facilities to support the population. However, in reality, this relatively low level of facility might not affect people's access to inpatient care in the regencies as these areas can be classified as urban, which have more options for inpatient care facilities (e.g., clinics and hospitals). On the contrary, some regencies such as Jembrana, Tabanan, Klungkung, Bangli, and Karangasem were constantly higher in LQ indices for PHC inpatient facility. This means that these Regencies have a high concentration of PHC with inpatient facility among the nine Regencies in Bali, as the LQ indices showed more than a fair share of facility. Simply put, these Regions had more than enough PHC with inpatient facility to meet public inpatient care needs.

Analysis of inpatient care demand revealed that there were four Regencies with demand levels exceeding the Province's average. These Regencies were Jembrana, Tabanan, Klungkung, and Karangasem. These Regencies are located relatively remote to the provincial city, except for Tabanan. Jembrana, Klungkung, and Karangasem had relatively fewer hospitals; thus, this might have reflected the high demand for inpatient care in these Regencies. However, though Tabanan Regencies had a fair number of hospitals and PHCs, this Regency still showed high demand for inpatient care. While, Bangli Regency, which had a relatively high inpatient facility in terms of PHC, showed low demand for inpatient care. This Regency also had few hospitals compared to other Regencies. The people of Bangli may have sought inpatient care in neighboring Regencies, such as Denpasar.

Analysis of healthcare distribution based on location quotient could give intuitive information related to accessing healthcare, and it allows for between area comparison. In spite of that, this study should be interpreted in the light of some limitations. First, this study only analyzed PHCs inpatient facility and demand; thus, the facility and demand level of inpatient care might not reflect the actual healthcare supply and demand. Secondly, this study measured facility and demand solely based on one variable: number of beds and number of inpatient, respectively. Further analysis using multilayer variables can be carried out to measure these dimensions more comprehensively.

\section{Conclusion}

Employing the location quotient method, we explored the distribution of PHCs inpatient facility and demand in Bali from 2015 to 2019. Our study found that there was variation in facility and demand for inpatient care in primary healthcare centers in Bali. A low level of inpatient facility was seen in Regency of Buleleng, Denpasar, and Gianyar, while high demand for inpatient facility was observed in Regency of Jembrana, Tabanan, Klungkung, and Karangasem. A unique finding was also noticed in Bangli Regency, where the PHCs inpatient facility was high, while the inpatient demand was low. This might indicate a need for evaluation of PHCs inpatient facility in this Regency. 


\section{References}

1. Fortney J, Rost K, Warren J. Comparing alternative methods of measuring geographic access to health services. Health Services and Outcomes Research Methodology. 2000;1(2):17384.

2. World Health Organization. State of health inequality: Indonesia: World Health Organization; 2017.

3. Benotti E, Hirschhorn L, Sugiyarso S, Ahmad J. Indonesia: Puskesmas and the road to equity and access. 2018.

4. Yang D-H, Goerge R, Mullner R. Comparing GIS-based methods of measuring spatial accessibility to health services. Journal of medical systems. 2006;30(1):23-32.

5. Photis YN. Disease and health care geographies: Mapping trends and patterns in a GIS. Health Science Journal. 2016;10(3):1.

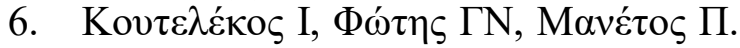
Geographic Information Analysis and Health Infrastructure. 2014.

7. McLafferty SL. GIS and health care. Annual review of public health. 2003;24(1):25-42.

8. Dummer TJ. Health geography: supporting public health policy and planning. Cmaj. 2008;178(9):1177-80.

9. Higgs G. A literature review of the use of GIS-based measures of access to health care services. Health Services and Outcomes Research Methodology. 2004;5(2):119-39.

10. Miller MM, Gibson LJ, Wright NG. Location quotient: A basic tool for economic development analysis. Economic Development Review. 1991;9 (2):65.

11. Abdullahi A, Abdullahi UY. The Use of Location Quotient (LQ) to Determine the Spatial Concentration of Health Care Facilities in Relation to Population in Gombe State. 2019.

12. Efransyah LL, Hasanbasri M. Akses Pelayanan Puskesmas Setelah Kebijakan Pelayanan Kesehatan Gratis Di Kota Lubuk Linggau. KMPK; 2010.
13. Rumengan DS, Umboh J, Kandou G. Faktor-faktor yang berhubungan dengan pemanfaatan pelayanan kesehatan pada peserta BPJS kesehatan di Puskesmas Paniki Bawah Kecamatan Mapanget Kota Manado. Jikmu. 2015;5(2).

14. Suparmi IBMH, Lestari H. Health Insurance as a Solution for Barriers to Maternal Healthcare Access in Indonesia. Jakarta; 2019.

15. Johar M, Soewondo P, Pujisubekti R, Satrio HK, Adji A. Inequality in access to health care, health insurance and the role of supply factors. Social Science \& Medicine. 2018;213:134-45.

16. Nurcahyo H, Bachtiar A, editors. Analysis of the Problems of General Practitioners Distribution in Community Health Centers (Puskesmas) in Indonesia. 4th International Symposium on Health Research (ISHR 2019); 2020: Atlantis Press.

17. Mujiati M, Yuniar Y. Ketersediaan sumber daya manusia kesehatan pada fasilitas kesehatan tingkat pertama dalam era Jaminan Kesehatan Nasional di delapan Kabupaten-Kota di Indonesia. Media Penelitian dan Pengembangan Kesehatan. 2016;26(4):201-10.

18. Soewondo P, Johar M, Pujisubekti R, Halimah $\mathrm{H}$, Irawati DO. Inspecting Primary Healthcare Centers in Remote Areas: Facilities, Activities, and Finances. Jurnal Administrasi Kesehatan Indonesia. 2019;7(1):89-98.

19. Dinas Kesehatan Provinsi Bali. Profil Kesehatan Provinsi Bali Tahun 2015. In: Bali DKP, editor. Denpasar2016.

20. Dinas Kesehatan Provinsi Bali. Profil Kesehatan Provinsi Bali Tahun 2016. In: Bali DKP, editor. Denpasar2017.

21. Dinas Kesehatan Provinsi Bali. Profil Kesehatan Provinsi Bali Tahun 2017. In: Bali DKP, editor. Denpasar2018.

22. Dinas Kesehatan Provinsi Bali. Profil Kesehatan Provinsi Bali Tahun 2018. In: Bali DKP, editor. Denpasar2019.

23. Dinas Kesehatan Provinsi Bali. Profil Kesehatan Provinsi Bali Tahun 2019. In: Bali DKP, editor. Denpasar2020. 
WMJ (Warmadewa Medical Journal), Vol. 6 No. 1, Mei 2021, Hal. 29

24. Geospasial I. Download Kumpulan Shapefile (SHP) Terlengkap dan Terbaru Seluruh Indonesia 2020 [Available from: https:// www.indonesia-geospasial.com/.
25. Rizki MR. Analisis Kepuasan Pelanggan Rawat Inap Puskesmas Berdasarkan Experiential Marketing. Jurnal Manajemen Kesehatan Yayasan RS Dr Soetomo. 2015;1(1):84-95. 